\title{
WOMEN IN ENGINEERING, FACULTY OF ENGINEERING IN BILBAO
}

\author{
F. Javier Maseda Rego ${ }^{1}$, Itziar Martija López ${ }^{1}$, Patxi Alkorta Egiguren ${ }^{2}$, \\ Izaskun Garrido Hernández ${ }^{1}$ \& Aitor J. Garrido Hernández ${ }^{1}$ \\ ${ }^{1}$ Automatic Control Group (ACG), Institute of Research and Development of Processes, \\ Faculty of Engineering in Bilbao, University of the Basque Country (UPV/EHU) (Spain) \\ ${ }^{2}$ Engineering School of Gipuzkoa, University of the Basque Country (UPV/EHU) (Spain)
}

\begin{abstract}
The situation of women in the engineering world has different aspects. On the one hand, it can be stated that women are well received in certain areas of the technological world, and they are very integrated into academia. In other areas, such as the world of industrial business, recognition is more complex being those less open environments.

Last century, the woman who broke the taboo in Spain was the mayor of Bilbao and the first industrial engineer graduated in Spain in 1912, Pilar Careaga. By means of her public presence, her message could reach the general society, but as something exceptional. At the Faculty of Engineering in Bilbao, the first female Industrial Engineer was Pilar Ipiña, graduated in 1965. Fifty-three years had passed.

Women in Engineering, more than a century later, remain a clear minority. While it is true that the presence of women in engineering schools is socially fully accepted, it is no less true that many young women dismiss the possibility of approaching that world from an early age. The lack of benchmarks seems to be a clear factor. Many of the engineers who are being interviewed in the search for ideas to motivate girls and young women, end up seeing lacks of references when asked about it.

While the experience of being a woman in such a traditionally male field has lights and shadows, reflect of what can be seen in different referenced studies, a positive message must be transmitted, as this has been the experience of both engineering students and workers in academia or in the business world.

Proposing solutions to smooth out the differences in numbers between men and women in the world of Engineering and Science requires knowing the causes, in order to be able to carry out actions that lead to collecting women's talent and with the appropriate training give it all the value that can achieve, both in the improvement of society as a whole and in the personal development of each of them. The aim is to achieve real equal choice between women and men and put everyone at the service of a better society. Equality is theoretically achieved, but it can still be improved.
\end{abstract}

Keywords: Women in engineering, engineering education, gender.

\section{Introduction: The choice of studies, the influence of the family and social mobility}

During childhood and adolescence, school, high school and university are a very important source of references for children. The referents are a fundamental factor in the perception of what is appropriate or accessible for girls. However, these examples of women girls may want to look like should be close, not only important. A woman astronaut or Nobel laureate may be admirable, but she can be someone unattainable and therefore impossible to imitate. However, the teachers of physics and chemistry, technical drawing or mathematics are women; they can be a more influencing factor, for being an achievable goal, in the view that technology, engineering or science are girls' things (Ayuso, Baldassarri, Trillo, Aragüés, Masiá, Molina, Murillo, Cerezo \& Villarroya, 2019).

The family environment also plays a fundamental role when choosing the field in which to pursue higher education. Not discouraging girls with comments about the difficulty of science or engineering studies is very important not to take them away from a fascinating world where discoveries, pure research, and inventions are waiting for talent (Ayuso, Fillola, Masiá, Murillo, Trillo-Lado, Baldassarri, Cerezo, Ruberte, Marical \& Villarroya-Gaudó, 2020).

Actions are being developed from the university world and from professional associations to promote that female talent is not lost in these areas, and actions are being taken to explain all these possibilities to girls and young women, but it is no less important that the family and community is 
informed and aware. Girls have no problem with science or technology subjects, and it should be natural for them to enjoy those disciplines. Interesting readings about women in science and technology can bring not just girls, but families, closer to the world of science and engineering (Tietjen and Reynolds, 1999).

Social mobility could be defined as the movement from one social position to another. University studies in engineering are linked to social mobility, including possibilities of occupation, something important for equal opportunities for boys and girls. Continuing studies is even more differentiating for women than for men (Neglia, Tragodara, Paragulla \& Caceres, 2020).

In terms of probability of attaining higher education, Spain is in position 8 out of 20 European countries, and has improved through the last generations (CRUE, 2018). Among people from 45 to 59 years of age, the percentage of adults who attained higher education and whose parents did not have them is $16 \%$, and among those from 30 to 44 it improves to $21 \%$ (CRUE, 2018).

An important piece of information to assess the possibility of social mobility is the number of universities in Spain and their territorial distribution. There are 50 public universities and 34 private universities in Spain (CRUE, 2019). The geographical proximity favours that families can financially support that young people access university studies. From the data (CRUE, 2018), (CRUE, 2019) it can be extracted that the percentage of women who access higher education is larger than that of men.

Figure 1 shows a report on Public Universities in Spain (CRUE, 2019) about women first enrolment. The orange colour corresponds to ten of twelve bachelor's degrees of the Faculty of Engineering in Bilbao.

Figure 1. Women first enrolment in Public Universities in Spain.

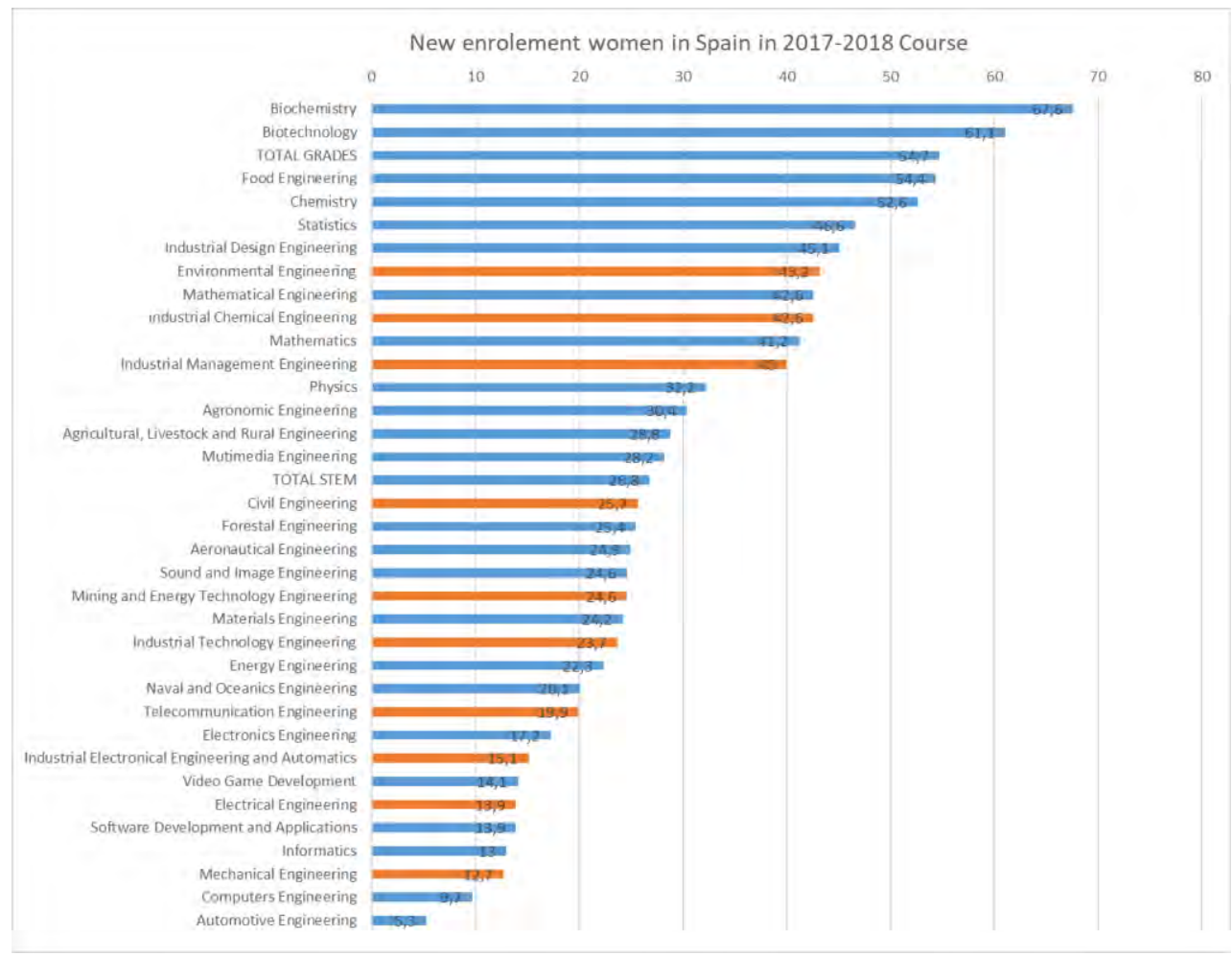

Reversing this trend and recovering women who like engineering fields is a social objective that will benefit everyone (De Carvalho Fernandes, Madeira, Da Gama Afonso, Da Silva Duarte, De Souza \& Peixoto, 2019).

\section{Women in academic world. Faculty of engineering in Bilbao}

Once women enrol on engineering studies at the university, even today, they are living in a very masculine environment. This is generally friendly and gender considerations are not carried over to the classroom. In the 1960s, 70s, or 80s, the female presence was testimonial but the student experience was generally satisfactory (Udén, 2002). Normality in dealing with teachers and classmates was the standard then and continues to be so today. No differentiating attitudes were perceived by gender, neither by the teaching staff nor by the peers. 
In the Faculty of Engineering in Bilbao in the 90s, 5 women and 95 men were in their sixth year of Industrial Engineering, Mechanical Degree. Considering 2014/15 to 2019/20 courses, 30 years later, the average ratio of enrolled women is $13 \%$.

The Faculty of Engineering in Bilbao has enrolled 4702 students distributed in their twelve engineering bachelor's degrees and eighteen master's degrees in 2019/20 course.

Figure 2 shows two blocks of graphics, the first one including gender distribution for the new incoming students of four bachelor's degrees and, at the second one showing the percentage of total new incoming women in the Faculty of Engineering in Bilbao. These graphics clearly confirm the reality of women in engineering degrees being a small proportion of the total students and the tendency does not improve along these years.

Figure 2. New incoming students in four bachelor's degrees and total new incoming women in the Faculty of Engineering in Bilbao, 2014/15 to 2019/2020 courses.
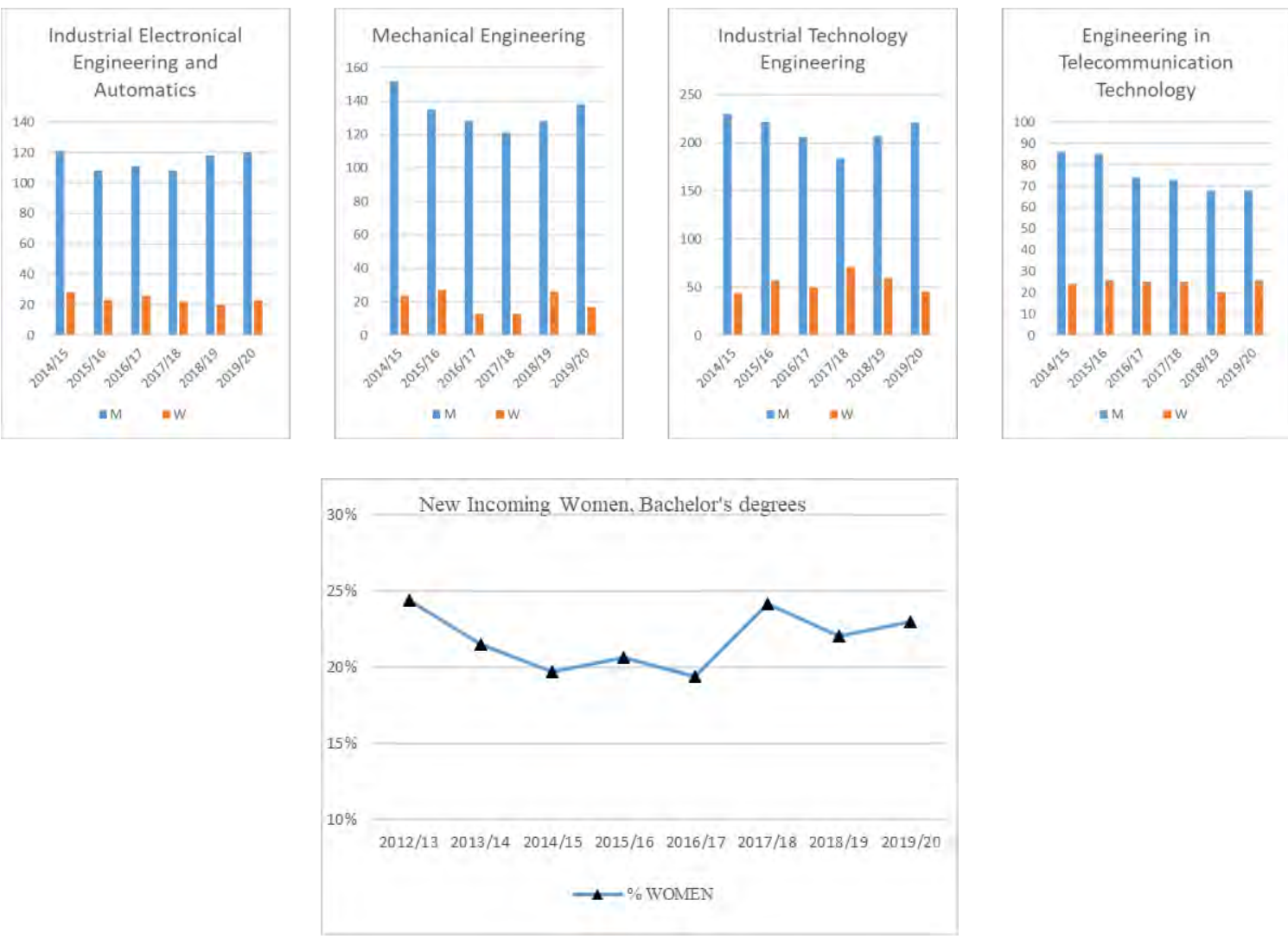

It is important to highlight that the dropout rate in the first year of undergraduate studies is lower among women, $18.1 \%$ compared to $23.2 \%$ for men (CRUE 2018). The percentage of credits passed compared to those enrolled, continues to be higher among women, $73.2 \%$ compared to $66.5 \%$ for men (CRUE 2018).

It seems clear, in view of the aforementioned data, that female engineering students are perfectly equipped for these studies. These data should reinforce the vision of young women, who could be deciding their studies and their professional future, that there is no objective reason that should separate them from their vocations (Mozahem, Ghanem, Hamied \& Shoujaa, 2019).

\section{The work environment and the glass ceiling}

The engineer professional career is a very flexible profession, being the knowledge fields in the careers highly diverse. In addition, the engineering graduate will be able to practice the profession after obtaining the title and without any additional requirement. These two circumstances allow the entrance in the work environment with certain easiness. Industry, academic, research, administration and business are different areas where engineers can develop their professional life.

Taking public universities and administration in Spain as example of women in different work positions, Table 1 shows the differences between men and women (Ministry of Science, Innovation and 
Universities, 2018). The results are revealing and this gender inequality could be extrapolated to other environments, especially taking into account that gender polices are regulated through different laws in the public administration. In the industry, data show similar differences (Fouad, Singh, Cappaert, Chang \& Wan, 2016).

Table 1. Ratio women/men in University and Governing institutions in Spain, 2018.

\begin{tabular}{|c|c|c|c|c|c|c|c|c|}
\hline & $\begin{array}{l}\text { Universities } \\
\text { in Spain }\end{array}$ & $\begin{array}{l}\text { Universities } \\
\text { in Spain }\end{array}$ & $\begin{array}{l}\text { Faculties } \\
\text { in Spain }\end{array}$ & $\begin{array}{l}\text { Faculties } \\
\text { in Spain }\end{array}$ & $\begin{array}{l}\text { Research } \\
\text { Institutes } \\
\text { in Spain }\end{array}$ & $\begin{array}{l}\text { Public } \\
\text { Institutions } \\
\text { in Spain }\end{array}$ & $\begin{array}{l}\text { Public } \\
\text { Institutions } \\
\text { in Spain }\end{array}$ & $\begin{array}{l}\text { Faculty } \\
\text { Engineering } \\
\text { in Bilbao }\end{array}$ \\
\hline & $\begin{array}{l}\text { Rectors/ } \\
\text { deans }\end{array}$ & Vice-rectors & $\begin{array}{l}\text { Faculty } \\
\text { directors }\end{array}$ & $\begin{array}{l}\text { Vice- } \\
\text { directors }\end{array}$ & Directors & $\begin{array}{l}\text { Grade D, } \\
\text { the lowest }\end{array}$ & $\begin{array}{c}\text { Grade A, } \\
\text { the highest }\end{array}$ & Lecturers \\
\hline Women & $2 \%$ & $39 \%$ & $27 \%$ & $47 \%$ & $19 \%$ & $58 \%$ & $25 \%$ & $34 \%$ \\
\hline Men & $98 \%$ & $61 \%$ & $73 \%$ & $53 \%$ & $81 \%$ & $42 \%$ & $75 \%$ & $66 \%$ \\
\hline
\end{tabular}

Higher studies provide a qualification that generally allows graduates to achieve quality employment. One of the objectives of the students is to have successful access to employment and data demonstrate that university education fulfils its purpose (Ministry of Science, Innovation and Universities, 2018). However, today there are still both a wage gap and a higher unemployment rate for women (Cadaret, Hartung, Subich \& Weigold, 2017). Many women still face the double challenge: that of moving up socially and that of breaking different barriers of inequality, like the 'pregnancy penalty' (Vella, 2020).

When analysing the impact that studying science or engineering has on female university graduates, one could say that there is good news. The higher the qualification, the better employment rate. In addition, the fields of engineering and science have one of the highest occupancy rates. Combining both factors, there are even more reasons to encourage women to choose these studies (Mills, Gill, Sharp \& Franzway, 2011).

Work environment is one of the most complex ones for women in engineering, as reaching management positions continues to be more difficult for women. Many highly trained and experienced women, including many not having children, have hit the named 'glass ceiling'. (Mozahem, Ghanem, Hamied \& Shoujaa, 2019).

\section{Conclusions and possible actions}

Exploring solutions in gender differences is a complex problem. Equitable representation of women is essential for the normalization of the female presence. It is necessary that female engineers are working to their abilities and developing their talents to make their presence natural, and in this way, they must reach decision-making positions.

In primary and secondary education, having female references in engineering fields helps normalize girls' vision of their possible choice of engineering or technology fields. Visibility of women who work in engineering and science must be promoted so that it is perceived as something natural and these options are chosen with the same spontaneity with which girls choose to be a doctor, a psychologist, or a teacher.

The fear of an insufficient professional projection after very demanding studies can also keep girls away from the world of engineering. Knowledge of the reality of labour insertion of women in the industry with a high professional category is also motivating.

It must be recognized that in order to change situations with great inertia like this one, actions must be taken to break the current imbalance.

\section{Acknowledgements}

This work was supported in part by the Basque Government, through project IT1207-19 and by the MCIU/MINECO through RTI2018-094902-B-C21/RTI2018-094902-B-C22 (MCIU/AEI/FEDER, UE). 


\section{References}

Ayuso, N., Baldassarri, S., Trillo, R., Aragüés, R., Masiá, B., Molina, P., Murillo, A. C., Cerezo, E., \& Villarroya, M. (2019). Integral Actions Towards Women in Engineering Recognition. IEEE International Conference on Emerging Technologies and Factory Automation (ETFA), 1836-1840.

Ayuso, N., Fillola, E., Masiá, B., Murillo, A. C., Trillo-Lado, R., Baldassarri, S., Cerezo, E., Ruberte, L., Marical. M. D., \& Villarroya-Gaudó, M. (2020). Gender Gap in STEM: A Cross-Sectional Study of Primary School Students' Self-Perception and Test Anxiety in Mathematics. IEEE Transactions on Education, doi: 10.1109/TE.2020.3004075.

Cadaret, M. C., Hartung, P. J., Subich, L. M., \& Weigold, I. K. (2017). Stereotype threat as a barrier to women entering engineering careers. Journal of Vocational Behavior, 99, 40-51.

CRUE Spanish Universities. (2018). La Universidad Española en Cifras 2016/17. Spain. Legal deposit M-40802-2018. https:/www.crue.org/publicacion/espanola-en-cifras/

CRUE Spanish Universities. (2019). La Universidad Española en Cifras 2017/18. Spain. Legal deposit M-3628-202, ISBN 978-84-09-18182-7. https://www.crue.org/publicacion/espanola-en-cifras/

De Carvalho Fernandes, M. R., Madeira, V. R., Da Gama Afonso, H. C. A., Da Silva Duarte, K., De Souza, A. L. L., \& Peixoto, A. (2019). A Study on the Support for Women in Engineering Courses. IEEE Global Engineering Education Conference (EDUCON), 1237-1240.

Fouad, N. A., Singh, R., Cappaert, K., Chang, W., \& Wan, M. (2016). Comparison of women engineers who persist in or depart from engineering. Journal of Vocational Behavior, 92, 79-93.

Mills, J. E., Gill, J., Sharp, R., \& Franzway, S. (2011). Getting it together: Feminist interdisciplinary research on women and engineering. Women's Studies International Forum, 34, 13-19.

Ministry of Labour, Migration and Social Security. (2018). La situación de las mujeres en el mercado de Trabajo 2018. NIPO: 854-19-050-9. http://www.mitramiss.gob.es/es/sec_trabajo/analisis-mercadotrabajo/situacion-mujeres/situacion_mujer_trabajo_2018.pdf

Ministry of Science, Innovation and Universities. (2018). Cientificas en Cifras 2017, Estadísticas $e$ indicadores de la (des)igualdad de género en la formación y profesión científica, NIPO: 057180822.https://www.ciencia.gob.es/stfls/MICINN/Ministerio/FICHEROS/UMYC/Cientificas cifras_2017.pdf

Mozahem, N. A., Ghanem, C. M., Hamied, F. K., \& Shoujaa, R. E. (2019). Women in engineering: A qualitative investigation of the contextual support and barriers to their career choice. Women's Studies International Forum, 74, 127-136.

Neglia, L. F., Tragodara, K. S. C., Paragulla, J. V., \& Caceres, M. R. C. (2020). The presence of women in the Engineering Programs of the University of Sciences and Humanities. Motivations, permanence and monitoring. IEEE World Conference on Engineering Education (EDUNINE), 1-4.

Tietjen, J. S., \& Reynolds, B. (1999). Women engineers bridging the gender gap. International Symposium on Technology and Society - Women and Technology: Historical, Societal, and Professional Perspectives, 206-210.

Udén, M. (2002). The Impact of Women on Engineering: A study of Female Engineering Students' Thesis Topics. International Journal Engineering Education, 00, 1-7.

Vella, H. (2020). Leaving women to hold the baby: The real reason for the gender gap? Could addressing the 'pregnancy penalty' with equal parental leave policies for both mothers and fathers be a catalyst for retaining more women in the engineering and technology sector?. Engineering \& Technology, 15 (1), 52-55. 